\title{
РАЦІОНАЛЬНИЙ ПІДХІД ДО РЕАБІЛІТАЦІЇ ДІТЕЙ, ЯКИМ ВИКОНАНО РАДИКАЛЬНЕ ОПЕРАТИВНЕ ВТРУЧАННЯ З ПРИВОДУ ПІЛОНІДАЛЬНОЇ ХВОРОБИ
}

\author{
๑Р. В. Шавлюк', В. С. Конопліцький ${ }^{1}$, В. М. Шавлюк ${ }^{2}$ \\ Вінницький національний медичний університет імені М. І. Пирогова ${ }^{1}$ \\ КП "Козятинська чентральна районна лікарня"
}

РЕзЮМЕ. Пілонідальна хвороба - поширена патологія, історія вивчення якої є досить довгою. Проте досі немає одностайного рішення щодо показань до лікування, підходів та методів хірургічної корекції, плану подальшої реабілітації при цьому захворюванні.

Мета - розробка методики післяопераційного ведення дітей, яким виконане радикальне оперативне втручання з приводу пілонідальної хвороби.

Матеріал і методи. У нашій роботі наведено варіант ведення та реабілітації пацієнта, якому виконана операція, запропонована G. Е. Karydakis у 1992 році (методика Bascom II). Ïї вважають оптимальною через ряд переваг перед іншими методами хірургічного лікування.

Результати. Вважаємо, що ведення ділянки операційної рани доцільно поділити на декілька періодів, кожен з яких має свої особливості та правила, яких варто дотримуватись: передопераційний період, ранній післяопераційний період, віддалений післяопераційний період, пізній післяопераційний період.

Висновки. 1. Раціональний підхід до організації періопераційного та післяопераційного періодів у дітей із пілонідальною хворобою є важливим елементом реабілітації, що може значно зменшити частоту післяопераційних ускладнень та ризик рецидивів захворювання, а також зменшити дискомфорт пацієнта.

2. Необхідним є чітке дотримання алгоритму реабілітації дітей, оперованих з приводу пілонідальної хвороби, для стандартизації надання допомоги.

КЛючОВІ СЛОВА: пілонідальна хвороба; діти; реабілітація.

Вступ. Пілонідальна хвороба (ПХ) - один із термінів, трактування якого викликає багато питань у різних авторів. Серед медичної спільноти досі не існує однозначної думки, яку назву має вказана патологія, ґрунтуючись на поняттях етіопатогенезу, клінічних проявах та уявленнях, що мають суто історичне значення. Тому вона має понад 40 варіантів назв, що призводить до труднощів у інтерпретації вказаної патології [1]. Уперше цю патологію як самостійне захворювання описав A. Anderson (1847) у листі до редакції «Бостонського медичного хірургічного журналу» під назвою «наir extracted from an ulcer» («Волосся витягнуте із виразки») [2].

Відповідно до класифікації американської асоціації колоректальних хірургів, ПХ - це хронічна шкірна інфекція, яка локалізується на дні міжсідничної складки (у проекції крижово-куприкової ділянки). Але, на нашу думку, це визначення дещо обмежене й не повною мірою розкриває суть патології. Тому ми вважаємо необхідним доповнити це визначення, резюмуючи наступне: ПХ - це гострий пілонідальний абсцес або хронічне запалення епітеліальних куприкових ходів у підшкірно-жировій клітковині міжсідничної складки в проекції крижово-куприкової ділянки. Ці ходи анатомічно не зв'язані з останньою і можуть мати ознаки хронічного запалення та рецидивний перебіг.

Візуально ПХ у гострий період являє собою абсцес у ділянці міжсідничної складки, із усіма ти- повими ознаками запалення та без особливих анатомічних ознак при поверхневому огляді. Однак при детальному обстеженні крижово-куприкової ділянки можна визначити первинні та вторинні норицеві ходи у вигляді воронкоподібних втягнень шкіри, зазвичай у кількості 2-4, на відстані 0,3-1,0 см один від одного, розташованих на дні міжсідничної складки. У цих норицевих ходах можуть відмічатись явища гноєвиділення (частіше у одному із них, який $\epsilon$ вторинним норицевим отвором) та жмутки волосся (у первинних норицевих отворах).

ПХ крижово-куприкової ділянки належить до поширених захворювань дитячого віку, трапляється у 5-6,6 \% населення працездатного віку, що складає 15-25 \% усіх хворих проктологічного стаціонару та, відповідно, 1-2 \% пацієнтів хірургічного стаціонару $[3,4]$.

Незважаючи на більш ніж сторічну історію цієї патології, одним із перших науковців, що ґрунтовно займались ПХ, був Ј. Ваscom, який у 1980 році описав та висунув фолікулярно-ретенційну теорію виникнення цього захворювання, започаткувавши при цьому цілий напрямок наукових досліджень [5]. G. Е. Karydakis розвинув цю теорію, й у 1992 році опублікував дослідження, в якому проаналізував результати обстеження та лікування 6000 пацієнтів, в якому висунув та означив базові принципи оперативного лікування цієі патології [6]. Основною причиною розвитку ПХ 
Огляди літератури, оригінальні дослідження, погляд на проблему, випадок з практики, короткі повідомлення

J. Bascom та G. E. Karydakis вважали «проникнення» остриженого волосся у первинні норицеві ходи через хронічне пошкодження, дію сил тертя на дні глибокої та широкої міжсідничної складки і створення цим «присмоктувальної» іï дії. Тому основним моментом у дотриманні радикальності оперативного лікування ПХ G. Е. Кагуdakis вважав зменшення дії вказаних сил шляхом сплощення міжсідничної складки та латералізації післяопераційної рани для спрощення умов догляду за нею, покращення умов ії санації й загоєння.

Цей метод виконання вважають одним із кращих та широко застосовують у світовій практиці при лікуванні ПХ. Він асоціюється із низьким рівнем рецидивів захворювання (2-12 \% за даними різних досліджень) та відповідає рівню доказовості 1В $[7,8]$. Суть вказаної методики полягає у тому, щоб видалити масив тканин із епітеліальними куприковими ходами із використанням доступу, зміщеного своєю віссю латерально (у бік однієї із сідниць) від лінії міжсідничної складки. Надалі проводиться видалення масиву м'яких тканин, що містить пілонідальну кісту, до крижово-куприкової фасції. Після цього необхідно мобілізувати шкірно - підшкірно-жировий клапоть зі сторони ближчого до міжсідничної складки краю рани, провести ушивання рани таким чином, аби останній перемістився на протилежну сідницю. Така методика дозволяє досягти оптимізації умов для загоєння післяопераційної рани та сплощити міжсідничну складку, що зменшує ризик рецидивів вказаної патології.

Незважаючи на широкий інтерес науковців до методів хірургічної корекції ПХ, досить дискутабельним залишається момент реабілітації пацієнтів після радикальних оперативних втручань. У багатьох дослідженнях наводяться протилежні дані - одні автори наполягають на необхідності суворого режиму в ранній післяопераційний період, інші стверджують що необхідності обмеження фізичної активності немає.

Мета - розробка методики післяопераційного ведення дітей, яким виконане радикальне оперативне втручання з приводу пілонідальної хворо6и.

Матеріал і методи дослідження. У нашій роботі як основний метод радикальної корекції ПХ у дітей ми використовуємо операцію, запропоновану G. Е. Karydakis у 1992 році (методика Bascom II). Оптимальною її вважають через ряд переваг, порівняно з іншими методами хірургічнго втручання. По-перше, за рахунок сплощення міжсідничної складки зменшується ризик рецидивів пілонідальної хвороби. По-друге, значно покращуються умови загоєння рани за рахунок латералізації останньої. Тобто рана знаходиться не на дні міжсідничної складки, де на неї діє цілий комплекс негативних факторів, які здатні значно пролонгувати процес репарації тканин та спричинити дискомфорт пацієнту. До негативних чинників належать постійний механічний вплив унаслідок тертя сідниць при ході; порушення аерації рани через велику глибину міжсідничної складки, яка додатково збільшується у положенні стоячи; значні труднощі при щоденному туалеті міжсідничної складки через складність ретельного її миття унаслідок необхідності розведення сідниць, що може призводити до болючості; постійна дія кислого середовища поту (особливо у літній час) призводить до можливості розвитку мацерацій у вказаній ділянці й до дискомфорту пацієнта. Латералізація рани дає можливість уникнути дії цих негативних факторів та значно поліпшити можливість туалету післяопераційної рани, що, в свою чергу, покращує післяопераційний період для пацієнта й умови загоєння рани.

Результати й обговорення. Вважають, що ведення ділянки операційної рани доцільно поділити на кілька періодів, кожен з яких має свої особливості:

1. Передопераційний період;

2. Ранній післяопераційний період;

3. Віддалений післяопераційний період;

4. Пізній післяопераційний період.

Реабілітація дітей з ПХ починається ще на етапі передопераційного періоду. Важливим $\epsilon$ дотримання пацієнтом гігієни, так як при недбалому процесі миття у найглибших ділянках міжсідничної складки можуть зберігатись велика кількість остриженого волосся, продукти виділень шкірних залоз, а також вміст пілонідальних синусів. Це може призвести до мацерації шкіри у вказаній ділянці, що призведе до подовження процесу загоєння післяопераційної рани. Також важливим елементом профілактики післяопераційних ускладнень зі сторони рани є дефекація у день операції. Ми рекомендуємо усім пацієнтам після нічного сну очистити товсту кишку самостійно або із використанням адаптованих клізм. За канонами загальної хірургії, безпосередньо перед операцією ми виконуємо підготовку майбутнього операційного поля шляхом ретельного бриття та розмічування місця майбутньої операції (рис. 1).

Обов' язковою є пояснювальна бесіда з пацієнтом та його батьками щодо основних моментів виконання оперативного втручання, його методів та необхідності, правил поведінки у ранньому та відділеному післяопераційних періодах, можливостей та об'єму фізичної активності, ризиків появи рецидиву захворювання. Така бесіда дає можливість досягти комплаєнсу між пацієнтом та його батьками й лікарем, що дозволяє поклада- 


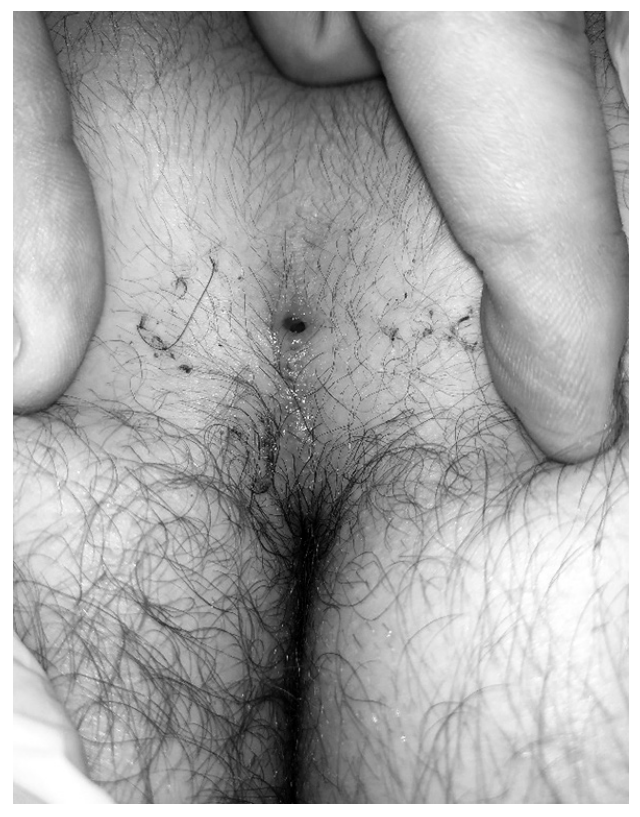

a

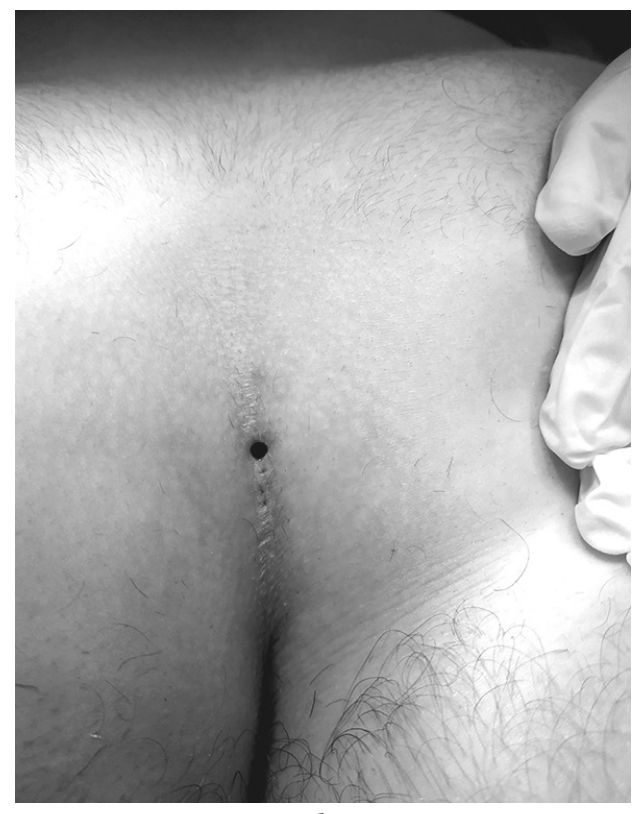

6

Рис. 1. Загальний вигляд ділянки міжсідничної складки до (а) та після (6) підготовки операційного поля.

тись на розуміння пацієнтом своєї проблеми й на те, що він не лише буде виконувати настанови, але й більш щадно ставитиметься до ділянки оперативного втручання.

Також проводиться медикаментозна підготовка пацієнта до виконання хірургічного втручання, яка включає антибіотикопрофілактику препаратом цефалоспоринового ряду III покоління, розчиненим у 100 мл ізотонічного розчину хлориду натрію, за 1 год до виконання хірургічного втручання внутрішньовенно крапельно; введення знеболювальних за 15-30 хвилин до початку операції. У нашій практиці з цією метою ми використовуємо парацетамол та декскетопрофен у вікових дозах. На завершальному етапі виконання хірургічного втручання, після проведення попередньої внутрішньошкірної алергічної проби, ми вводимо біпувокаїн 2,5 \% під крижово-куприкову фасцію та після закриття операційної рани виконуємо ії блокаду.

Ранній післяопераційний період $є$ дуже важливим та критичним з погляду подальшого періоду відновлення та загоєння рани. Ще перед операцією пацієнту пояснюють основні правила поведінки в цей період. Основними є профілактика розвитку гнійних ускладнень у рані, забезпечення умов для адекватного її загоєння та зменшення ризику післяопераційних ускладнень, що досягається організаційним та медикаментозним шляхом. По-перше, варто завершити антибіотикопрофілактику шляхом повторного введення добової дози цефалоспорину та призначення перорально метронідазолу у віковій дозі на 5 діб [7]. По-друге, дотримання адекватного знеболювання покращує комфорт пацієнта та пришвидшує загоєння рани внаслідок відсутності рефлекторного ангіоспазму як реакції на біль. Для цього протягом перших 2-3 діб після виконання хірургічного втручання ми призначаємо знеболювальні засоби: парацетамол, декскетопрофен та метамізол натрію у вікових дозах, що дозволяє досягти адекватного знеболювання без необхідності використання наркотичних анальгетиків. 33 дня пацієнта переводять на пероральну форму анальгетика (ібупрофен) з прийомом тричі на добу впродовж 3 діб, або із введенням знеболювальних засобів парентерально за вимогою хворого. По-третє, необхідна раціональна організація раннього післяопераційного періоду, оскільки він буде мати для дитини багато нових особливостей. Незважаючи на відсутність в іноземних літературних джерелах чітких даних щодо необхідності суворого ліжкового режиму у перші 3-4 доби післяопераційного періоду, ми вважаємо це доцільним, оскільки у цей час відбуваються найактивніші процеси проліферації та адгезії країв рани [9]. Ми рекомендуємо ліжковий режим протягом перших 3 діб після виконання оперативного втручання з можливістю обмеженої вертикалізації при потребі. Також ми рекомендуємо пацієнту більшість часу проводити лежачи на боках, на животі або на спині, із підкладеним під пошкоджену ділянку О-подібним валиком. Це значно зменшує тиск на ділянку післяопераційної рани, покращуючи її кровопостачання, що є важливим в умовах переміщення шкірного клаптя, та покращує фізіо- 
Огляди літератури, оригінальні дослідження, погляд на проблему, випадок з практики, короткі повідомлення логічно збіднену мікроциркуляцію, знижує больовий синдром. Уперше вертикалізувати пацієнта рекомендуємо із допомогою батьків, таким чином, щоб пацієнт якомога менше приводив стегна до тулуба (згинання у кульшових суглобах має бути не більше 35-40), щоб запобігти надмірному натягу шкіри в ділянці післяопераційної рани. В подальшому, після набуття відповідних навичок, пацієнт вставатиме самостійно. Після 4 дня післяопераційного періоду необхідності в обмеженні рухової активності пацієнта немає, але зберігається заборона приймати сидяче положення. Також пацієнту не рекомендовані підняття вантажів та хода по сходах.

Моментом, що спричиняє пацієнту значний дискомфорт, $є$ перші фізіологічні випорожнення. Через заборону приймати сидяче положення цей процес стає незвичним для дитини, що може призводити до стійких запорів. Ми рекомендуємо пацієнтам здійснювати акт дефекації стоячи, зі згинанням у стегново-поперековому куті не більше ніж на 35-40, або лежачи на боці, протилежному від того, куди був переміщений шкірно - підшкірно-жировий клапоть.

Важливим $є$ дотримання певних харчових обмежень, які допомагають пацієнту зменшити дискомфорт при акті дефекації та зробити його максимально комфортним. Для цього в ранньому післяопераційному періоді ми рекомендуємо пацієнтам висококалорійну їжу, із незначним вмістом клітковини та інших грубих домішок, з яких в подальшому формуються щільні калові маси. Такими продуктами можуть бути шоколад, арахіс, енергетичні батончики, які рекомендовані протягом перших днів післяопераційного періоду, оскільки вони сповільнюють кишковий транзит. Завдяки відстроченню першого акту дефекації можна значно зменшити навантаження на ділянку післяопераційної рани, яке створюється при цьому.

При подальшому харчуванні з метою нормалізації перистальтичної активності товстої кишки у комплексі лікувальних заходів в якості довгострокової дієти використовували дієтичний стіл № 3, ефект від якого досягається за рахунок застосування групи харчових продуктів, що сприяють спорожненню дистальних відділів товстої кишки та формують кашкоподібні випорожнення (тип 3-4 за Брістольською шкалою калу).

Весь спектр продуктів був поділений на підгрупи для більш глибокого розуміння їх специфічної ефективності і полегшення складання щоденного раціону харчування. Це мало важливе значення насамперед для батьків, які в процесі створення програми харчування повинні піклуватися про різноманітність і повноцінність раціону організму дитини.
1. Продукти, багаті на рослинну клітковину (овочі, фрукти, ягоди в сирому, вареному і печеному вигляді. Морська капуста, хліб з борошна грубого помелу, житній хліб, хліб з висівками, розсипчасті гречана, перлова і інші каші з рослинних злаків. Ці, більшою мірою баластні, продукти дають велику кількість неперетравлених залишків, які збуджують рухову активність травного каналу за рахунок механічного подразнення.

2. Цукристі речовини (тростинний і буряковий цукор, мед, сиропи, молочний цукор, маніт, декстроза, варення, солодкі страви, фрукти і соки тощо) сприяють залученню рідини в кишку з розрідженням калових мас і розвитку кислого бродіння, продукти якого збуджують секрецію і перистальтику кишок.

3. Продукти, що містять органічні кислоти (одно- і дводенний кефір, кисле молоко, кумис, фруктові соки, квас, кислий лимонад, кисла молочна сироватка), які збуджують секрецію кишок і їх перистальтичну активність.

4. Харчові продукти, багаті на сіль (солона вода, оселедець, солонина тощо). Натрію хлорид сприяє залученню рідини в кишку і розрідженню калових мас.

5. Жири та багаті на них продукти (вершкова, оливкова, соняшникова, кукурудзяна олія, риб'ячий жир, вершки, сметана, сало, шпроти, сардини в олії тощо). Вони сприяють розм'якшенню калових мас і роблять їх більш «слизькими».

6. Холодні харчові продукти (морозиво, окрошка, вода, лимонад, квас, борщ тощо) Подразнюють терморецептори і порушують рухову активність кишкової стінки.

7. Продукти, що містять або утворюють вуглекислоту (газована вода, мінеральні води тощо) збуджують перистальтичну активність за рахунок хімічного і, частково, механічного (розтягування кишкової стінки вуглекислим газом) подразнення. Продукти цієї підгрупи забезпечують також збільшення внутрішньокишкового і внутрішньочеревного тиску.

3 соків найкращий послаблювальний ефект мають буряковий, морквяний, капустяний, томатний, абрикосовий, сливовий.

Необхідно виключити з раціону харчування продукти, що уповільнюють кишковий транзит: міцний чай, какао, чорна кава, шоколад, кизил, гранат, брусницю, чорницю, груші, макаронні вироби, киселі, ніжні сири, гарячі напої і страви.

У пізньому післяопераційному періоді основним є дотримання чистоти післяопераційної рани. Відразу після видалення дренажів, що зазвичай здійснюється на 3-5 добу, пацієнтам рекомендовано приймати душ із використанням миючих засобів (мило, гель для душу) 1-2 рази на добу пе- 
Огляди літератури, оригінальні дослідження, погляд на проблему, випадок з практики, короткі повідомлення ред перев'язкою. Це забезпечує достатню аерацію рани та її ретельне очищення від продуктів функціонування шкірних залоз, що запобігає розвитку дерматиту. Важливо, щоб діти приймали душ під контролем батьків, які мають слідкувати за достатньою ретельністю миття пошкодженої ділянки, оскільки часто існує необґрунтований страх пошкодити або намочити ділянку рани.

Перев'язки проводять 1 раз на добу з використанням безспитрових антисептиків (повідон йод, октенідину дигідрохлорид, хлоргексидин 3 концентрацією діючої речовини не менше, ніж 0,5 \%), що дозволяє не спричиняти больових відчуттів дитині. Після зміни пов'язки рекомендовано проводити фізіотерапевтичні процедури: ультрафонофорез та електрофорез на ділянку післяопераційної рани №10 [10].

Тривалість стаціонарного лікування складає в середньому 8-12 діб, залежно від того, як активно відбувається процес загоєння післяопераційної рани. Шви знімають на 14-18 добу післяопераційного періоду.

Після виписування дитини на амбулаторне лікування продовжуються обмеження фізичної активності, заборона сидіння. В нашій практиці ми рекомендуємо дітям не сідати протягом 3 тижнів після зняття швів. Повернення до можливості повноцінного сидіння рекомендуємо тільки після повторного огляду хірурга. Ми практикуємо поступовий процес повернення пацієнта до нормального способу життя: рекомендуємо поступово збільшувати стегново-поперековий кут шляхом дозованого присідання з опорою спиною на стіну

\section{ЛITEPATУРA}

1. Цема Е. В. Рак пилонидальной кисты (обзор литературы) / Е. В. Цема // Онкологическая колопроктология. - 2012. - № 2. - С. 10-25.

2. Anderson A. Hair extracted from an ulcer / A. Anderson // Boston Med. Surgical Journal. - 1847. - Vol. 36 (4). P. 74-76.

3. Abo Gali Mohammad Suf'jan Assad. Пути оптимизации местного лечения острого нагноения эпителиального копчикового хода / Abo Gali Mohammad Suf'jan Assad. - Харків : ХНМУ, 2005. - 20 с.

4. Нечай И. А. Малоинвазивные методики в лечении пилонидальной болезни (обзор литературы) / И. А. Нечай // Вестник хирургии. - 2019. - №. 178 (3). C. 69-73.

5. Bascom J. Pilonidal disease: origin from follicles of hairs and results of follicle removal as treatment / J. Bascom // Surgery. - 1980. - Vol. 87 (5). - P. 567-572.

6. Karydakis G. E. Easy and successful treatment of pilonidal sinus after explanation of its causative process / G. E. Karydakis // Aust. N Z J Surg. - 1992. - Vol. 62 (5). P. 385-389.

протягом 7-14 діб, залежно від виразності ознак дискомфорту. Загалом дитині протипоказані заняття спортом та значні фізичні навантаження протягом 2 місяців.

Важлива також профілактика вростання волосся у післяопераційний рубець. Таке явище часто трапляється, коли у дитини виражений гіпертрихоз й структура волосся $є$ жорсткою. Для цього ми рекомендуємо видалення волосся навколо післяопераційного рубця на відстані не менше ніж 3-4 см від його краю з кожної сторони. Це варто здійснювати за допомогою лазерної епіляції волосся, шляхом використання кремів для депіляції або бриття кожні 10-14 діб впродовж мінімум 3 місяців після виписування зі стаціонару. Це дозволяє досягти адекватного загоєння операційної рани та значно зменшити ризик рецидивів [11]. Однак ватро зауважити, що існує закономірність, яка вказує на те, що бриття ділянки післяопераційної рани збільшує ризик рецидиву захворювання, порівняно з лазерною епіляцією [12].

Висновки: 1. Раціональний підхід до організації періопераційного та післяопераційного періодів у дітей із пілонідальною хворобою є важливим елементом реабілітації, який може значно зменшити частоту післяопераційних ускладнень та ризик рецидивів захворювання, а також зменшити дискомфорт пацієнта.

2. Необхідним $є$ чітке дотримання алгоритму реабілітації дітей, оперованих з приводу пілонідальної хвороби, для стандартизації надання допомоги.

7. Practice parameters for the management of pilonidal disease / S. R. Steele, W. B. Perry, S. Mills, W. D. Buie // Diseases of the Colon \& Rectum. - 2013. - Vol. 56 (9). P. 1021-1027.

8. Nichol P. F. Fundamentals of Pediatric Surgery. 2th ed / P. F. Nichol, M. D. Rollins II, C. S. Muratore. - Switzerland: Springer, 2017. - 935 p.

9. Anderson J. H. Day-case Karydakis flap pilonidal sinus / J. H. Anderson // Diseases of the Colon \& Rectum. 2008. - Vol. 51. - P. 134-138.

10. Кораблина С. С. Комплексный подход к лечению эпителиального копчикового хода [дисертация]. Ставрополь: Ставропольский государственный медицинский университет, 2014. - 128 с.

11. Connie H. L. Twelve common mistakes in pilonidal sinus care / H. L. Connie // Advances in Skin \& Wound Care. 2012. - Vol. 25 (7). - P. 324-332.

12. Pronk A. A. The effect of hair removal after surgery for sacrococcygeal pilonidal sinus disease: a systematic review of the literature / A. A. Pronk // Techniques in Coloproctology. - 2018. - Vol. 22 (1). - P. 7-14. 
Огляди літератури, оригінальні дослідження, погляд на проблему, випадок з практики, короткі повідомлення REFERENCES

1. Tsema, E.V. (2012). Rak pilonidalnoi kisty (obzor literatury) [Cancer of the pilonidal cyst (literature review)]. Onkologicheskaya koloproktologiya - Oncological Coloproctology, 2, 10-25 [in Russian].

2. Anderson, A. (1847). Hair extracted from an ulcer. Boston Med. Surgical Journal, 36 (4), 74-76.

3. Abo Gali Mohammad Suf'jan Assad. (2005). Puti optimizatsii mestnogo lecheniya ostrogo nagnoeniya epitelialnogo kopchikovogo hoda [Ways to optimize the local treatment of acute suppuration of the epithelial coccygeal passage]. Candidate's Extended abstract. Kharkiv: HNMU [in Russian].

4. Nechay, I.A. (2019). Maloinvazivnyye metodiki v lechenii pilonidalnoy bolezni (obzor literatury) [Minimally invasive techniques in the treatment of pilonidal disease (literature review)]. Vestnik khirurgii - Bulletin of Surgery, 178 (3), 69-73 [in Russian].

5. Bascom, J. (1980). Pilonidal disease: origin from follicles of hairs and results of follicle removal as treatment. Surgery, 87 (5).

6. Karydakis, G.E. (1992). Easy and successful treatment of pilonidal sinus after explanation of its causative process. Aust. N Z J Surg., 62 (5), 385-389.
7. Steele, S.R., Perry, W.B., Mills, S., \& Buie, W.D. (2013). Practice parameters for the management of pilonidal disease. Diseases of the Colon \& Rectum., 56 (9), 10211027.

8. Nichol, P.F., Rollins II, M.D., \& Muratore, C.S. (2017). Fundamentals of Pediatric Surgery. 2th ed. Switzerland: Springer.

9. John, H. (2008). Anderson. Day-case Karydakis flap pilonidal sinus. Diseases of the Colon \& Rectum, 51, 134138.

10. Korablina, S.S. (2014). Kompleksnyy podkhod k lecheniyu epitelialnogo kopchikovogo khoda An integrated approach to the treatment of epithelial coccygeal passage]. Doctor's thesis. Stavropol: Stavropol State Medical University [in Russian].

11. Connie, H.L. (2012). Twelve common mistakes in pilonidal sinus care. Advances in Skin \& Wound Care, 25 (7), 324-332.

12. Pronk, A.A. (2018). The effect of hair removal after surgery for sacrococcygeal pilonidal sinus disease: a systematic review of the literature. Techniques in Coloproctology, $22(1), 7-14$.

\title{
РАЦИОНАЛЬНЫЙ ПОДХОД К РЕАБИЛИТАЦИИ ДЕТЕЙ, КОТОРЫМ ВЫПОЛНЕНА ОПЕРАЦИЯ ПО ПОВОДУ ПИЛОНИДАЛЬНОЙ БОЛЕЗНИ
}

\author{
๑Р. В. Шавлюк ${ }^{1}$, В. С. Коноплицкий ${ }^{1}$, В. М. Шавлюк ${ }^{2}$
}

Винницкий национальний медицинский университет имени Н. И. Пирогова

$$
\text { КП "Казатинская центральная районная больница" }
$$

РЕЗЮМЕ. Пилонидальная болезнь - распространенная патология, история изучения которой является достаточно долгой. Однако до сих пор нет единогласного решения относительно показаний к лечению, подходов и методов хирургической коррекции, плана дальнейшей реабилитации при этом заболевании.

Цель - разработка методики послеоперационного ведения детей, которым выполнено радикальное оперативное вмешательство по поводу пилонидальной болезни.

Материал и методы. В нашей работе приведен вариант ведения и реабилитации пациента, которому выполнена операция, предложенная G. E. Karydakis в 1992 году (методика Bascom II). Ее считают оптимальной через ряд преимуществ перед другими методами хирургического лечения.

Результаты. Считаем, что ведение участка операционной раны целесообразно поделить на несколько периодов, каждый из которых имеет свои особенности и правила, которых следует придерживаться: периоперационный период, ранний послеоперационный период, отдаленный послеоперационный период, поздний послеоперационный период.

Выводы. 1. Рациональный подход к организации периоперационного и послеоперационного периодов у детей с пилонидальною болезнью является важным элементом реабилитации, может значительно уменьшить частоту послеоперационных осложнений и риска рецидивов заболевания, а также уменьшить дискомфорт пациента.

2. Необходимо четкое соблюдение алгоритма реабилитации детей, оперированных по поводу пилонидальной болезни, для стандартизации оказания помощи.

КЛючЕВЫЕ СЛОВА: пилонидальная болезнь; дети; реабилитация. 
Огляди літератури, оригінальні дослідження, погляд на проблему, випадок з практики, короткі повідомлення

\title{
A RATIONAL APPROACH TO THE REHABILITATION OF CHILDREN WHO UNDERWENT SURGERY BECAUSE OF PILONIDAL DISEASE
}

\author{
@R. V. Shavliuk', V. S. Konoplitskiy', V. M. Shavliuk ${ }^{2}$ \\ M. Pyrohov Vinnytsia National Medical University ${ }^{1}$ \\ Utility Company "Koziatyn Central Regional Hospital"2
}

SUMMARY. Pilonidal disease is a common pathology, the history of which is quite long. But despite this, there is still no unanimous decision as to the indications for treatment, the approaches and methods of its surgical correction, the plan of further rehabilitation.

The aim of the study - to develop a procedure for postoperative management of children who have undergone radical surgery for pilonidal disease.

Material and Methods. In our work, we provide an option for the management and rehabilitation of a patient who has undergone surgery proposed by G.E. Karydakis in 1992 (Bascom II technique). It is considered optimal because of a number of advantages over other methods of surgery.

Results. We believe that it is advisable to divide the management of the wound area into several periods, each of which has its own peculiarities and rules that should be observed: preoperative period, early postoperative period, long postoperative period, late postoperative period.

Conclusions. 1. A rational approach to the organization of perioperative and postoperative periods in children with pilonidal disease is an important element of rehabilitation, which is able to significantly reduce the incidence of postoperative complications and the risk of relapse, as well as to reduce patient discomfort.

2. There is a need for a clear adherence to the algorithm for rehabilitation of children operated on for pilonidal disease to standardize care delivery.

KEY WORDS: pilonidal disease; children; rehabilitation.

Отримано 22.08.2019 